Nova Southeastern University

Florida

NOVA SOUTHEASTERN

UNIVERSITY

NSUWorks

Marine \& Environmental Sciences Faculty Articles Department of Marine and Environmental Sciences

$1-1-1996$

\title{
A 240-Year Stable Oxygen and Carbon Isotopic Record in a Coral from South Florida: Implications for the Prediction of Precipitation in Southern Florida
}

Peter Koenraad Swart

University of Miami

Richard E. Dodge

Nova Southeastern University, dodge@nova.edu

Harold J. Hudson

National Oceanic and Atmospheric Administration

Find out more information about Nova Southeastern University and the Halmos College of Natural Sciences and Oceanography.

Follow this and additional works at: https://nsuworks.nova.edu/occ_facarticles

Part of the Marine Biology Commons, and the Oceanography and Atmospheric Sciences and Meteorology Commons

\section{NSUWorks Citation}

Peter Koenraad Swart, Richard E. Dodge, and Harold J. Hudson. 1996. A 240-Year Stable Oxygen and Carbon Isotopic Record in a Coral from South Florida: Implications for the Prediction of Precipitation in Southern Florida .PALAIOS : 362 -375.

https://nsuworks.nova.edu/occ_facarticles/77. 


\title{
A 240-Year Stable Oxygen and Carbon Isotopic Record in a Coral from South Florida: Implications for the Prediction of Precipitation in Southern Florida
}

\author{
PETER KOENRAAD SWART \\ Marine Geology \& Geophysics, Rosenstiel School of Marine and Atmospheric Science, University of Miami, \\ 4600 Rickenbacker Causeway, Miami FL 33149
}

RICHARD E. DODGE

Southeastern Nova University, Oceanographic Center, 8000 North Ocean Dr, Dania FL 33004

HAROLD J. HUDSON

National Oceanographic \& Atmospheric Administration/Florida Keys National Marine Sanctuary, P.O. Box 1083, Key Largo FL 33149

PALAIOS, 1996, V. 11, p. 362-375

This study reports on the $\delta^{18} \mathrm{O}$ and $\delta^{13} \mathrm{C}$ composition of the skeleton from a 240-year-old specimen of Montastraea faveolata growing in Biscayne National Park, South Florida. Annual variations in the $\delta^{18} \mathrm{O}$ of the skeleton deposited during the summer months show a bimodal correlation with summer rainfall. During wetter years, the $\delta^{18} \mathrm{O}$ of the coral skeleton and the amount of precipitation during the summer months are inversely correlated $(r=-0.7)$ reflecting dilution of the seawater by meteoric water lower in $\delta^{18} \mathrm{O}$. During years in which summer rainfall is less than normal, increases in precipitation are positively correlated with skeletal $\delta^{18} O(r=+0.6)$ reflecting the input of freshwater from the Everglades higher in $\delta^{18} O$. Based on this correlation the $\delta^{18} \mathrm{O}$ record of the coral skeleton suggests that the 19th and 18th centuries have been relatively dry compared to the 20th century. Carbon isotopic compositions of the skeleton are positively correlated with $\delta^{18} O$, with the minimum in $\delta^{13} \mathrm{C}$ occurring several months after the minimum in $\delta^{18} \mathrm{O}$. Since the mid 1930s there has been a decrease in $\delta^{13} \mathrm{C}$ of the skeleton. Explanations for this trend may be (1) it reflects the increased input of carbon derived from the destruction of terrestrial ecosystems, (2) its part of a long-term decrease in $\delta^{13} \mathrm{C}$ associated with increased addition of fossil fuel-derived $\mathrm{CO}_{2}$.

\section{INTRODUCTION}

This paper reports the $\delta^{18} \mathrm{O}$ and $\delta^{13} \mathrm{C}$ of the skeleton of a specimen of Montastraea faveolata collected from Biscayne National Park in 1986. The coral was chosen because it has one of the longest growth records known from Biscayne National Park (Hudson et al., 1994) and therefore has the potential to provide an insight into the climatic and hydrologic history of this portion of the Florida reef tract. This region is influenced seasonally by outflow from Biscayne Bay which in turn is affected by discharge from the Florida mainland and local precipitation. Of particular interest are potential patterns of $\mathrm{C}$ and $\mathrm{O}$ isotopic variations prior to anthropogenic influences in the area and variations of freshwater influence and their relationships to precipitation.

\section{Background}

Biscayne National Park is situated at the southern end of the Florida peninsula (Fig. 1) close to the city of Miami. The reef from which this particular coral was cored is located approximately $6.5 \mathrm{~km}$ southeast of Elliot Key $\left(25^{\circ} 23.42 \mathrm{~N}, 80^{\circ} 10.29 \mathrm{~W}\right)$ between Hawk Channel and the shelf edge. The reef rises from a water depth of approximately $15 \mathrm{~m}$ and at the time of coring was within $2 \mathrm{~m}$ of the surface. 


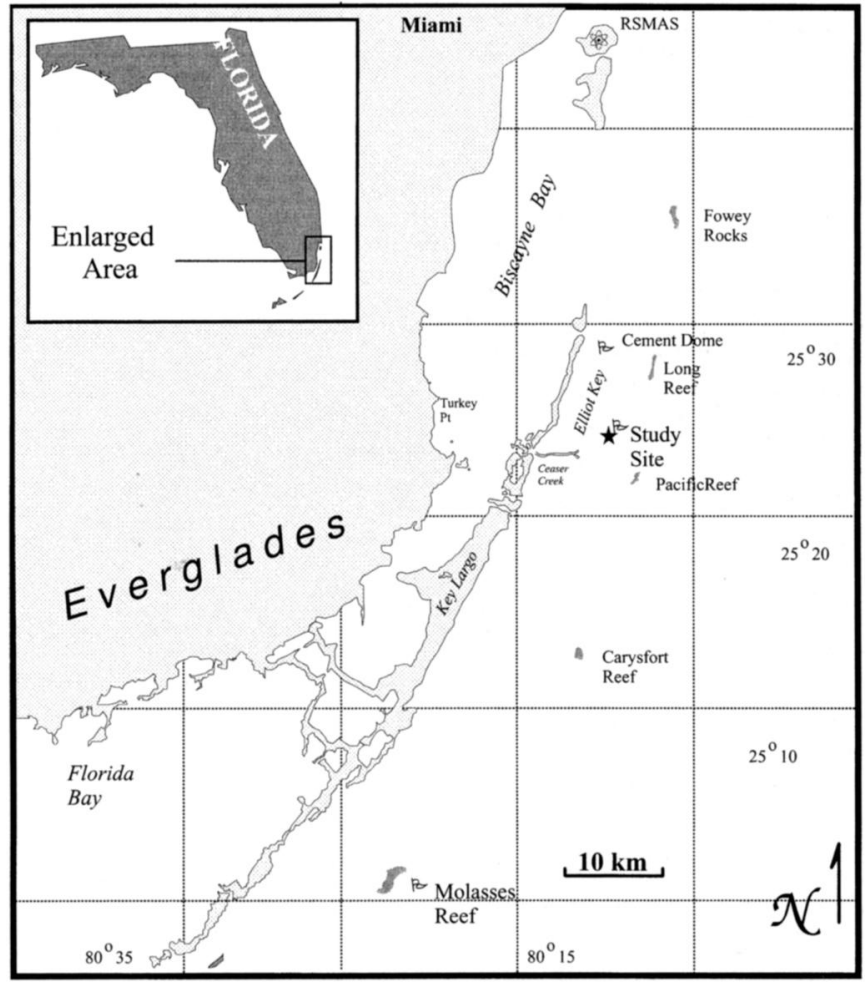

FIGURE 1-Location map showing position of Biscayne National Park, Alina's reef, and Cement Dome Reef.

\section{Water Temperature}

The water temperature in this area typically ranges from 18 to $32^{\circ} \mathrm{C}$, with monthly averages ranging between 20 and $30^{\circ} \mathrm{C}$.

\section{Salinity}

The area from which the coral was sampled is affected by waters which vary between slightly elevated and slightly reduced salinities relative to marine waters. The reason for this variation arises because the area is affected by outflow from Biscayne Bay through Caesar's Creek (Fig. 1). Although salinity data have been collected from the C-Man station at Fowey, this collection only started in 1991. The salinity of Biscayne Bay is in turn influenced by evaporation and discharge of freshwater from the Everglades and the canal system maintained by the South Florida Water Management District (SFWMD). During periods of excess precipitation, the salinity of the waters is depressed. In contrast during drier periods salinities are enhanced. During the early 20 th century there were abundant springs along the coast line of Biscayne Bay which contributed large amounts of freshwater to the Bay (Parker, 1984). In the early 1950's a large number of canals were built to drain the east Everglades. The canals diverted water across coastal ridge into Biscayne Bay. This had the effect of lowering the hydraulic head and effectively stopping the discharge of water through springs. No long term salinity measurements in the area.

\section{Climate}

The region experiences a sub-tropical climate with air temperature ranging between $32^{\circ} \mathrm{C}$ during the summer months (July-September) and $18^{\circ} \mathrm{C}$ during the winter (December-January). There is a pronounced wet season extending from July to September during which approximately $50 \%$ of the yearly average of $140 \mathrm{~cm}$ of precipitation occurs. Long term records of precipitation for the area exist back to 1896 (SFWMD, unpublished).

\section{Isotopic Composition of Florida Waters}

The isotopic hydrology of South Florida is unusual in that the large standing body of water which makes up the Everglades is isotopically enriched in ${ }^{18} \mathrm{O}(0$ to $+2 \%)$ as a result of intense evaporation (Meyers et al., 1994). The isotopic composition of precipitation is highly variable, but generally averages approximately $-3 \%$ (Swart et al., 1989), while the $\delta^{18} \mathrm{O}$ of ocean water lies between 0 and $+1 \%$ and is affected by the strength of the loop current, output from the Mississippi), and evaporation (Ortner et al., 1995).

\section{Stable Isotopes in Scleractinian Coral Skeletons}

Many scleractinian corals can be long-lived (hundreds to thousands of years) producing massive calcareous skeletons. Two features of these skeletons have proven to be extremely useful to geologists, geochemists, climatologists and environmental scientists in reconstructing growth rates and paleo-environments: These are (1) alternating bands of high and low density skeletal material, where each pair of bands represents approximately one year's growth, and (2) the chemical composition of the skeletal material. Sclerochronology, based on the assumption of annual periodicity of the high/low density band pair, has been used alone to date past environmental conditions that have resulted in increased or decreased growth rates of corals (Dodge and Vaisneys, 1975; Weber et al., 1975; Hudson et al., 1976; Schneider and Smith, 1982; Dodge and Lang, 1983; and others), or together with other signals in the skeleton to investigate processes; such as major episodes of river runoff that leave fluorescent bands in the skeleton (Isdale, 1984), pollution events (Dodge et al., 1984; Dodge and Gilbert, 1984), or mixing rates of the ocean from bomb-derived C-14 (Druffel, 1982, 1987).

The $\mathrm{C}$ and $\mathrm{O}$ isotopic compositions of coral skeletons have been studied by numerous workers (Keith and Weber, 1965; Weber and Woodhead, 1970;1972; Land et al., 1975a, 1975b; Weber et al., 1975, 1976; Goreau 1977; Fairbanks and Dodge, 1979; Swart and Coleman, 1980; Swart, 1983; Weil et al., 1981; Patzold, 1984; McConnaughey, $1986,1989 \mathrm{~b}$; and others). For a review the reader is referred to Swart (1983) and McConnaughey, (1989a). While it has been reasonably well established that the $\mathrm{O}$ isotopic 
composition of the skeleton is negatively correlated with temperature as a result of normal equilibrium or perhaps kinetic processes (Weber and Woodhead, 1972; Fairbanks and Dodge, 1979; Weil et al., 1981; McConnaughey, 1989a, b), the $\mathrm{C}$ isotopic composition of zooxanthellate coral skeletons frequently exhibits a variability which bears no relationship to easily quantifiable environmental variables such as temperature and insolation. The $\mathrm{O}$ isotopic composition of coral skeletons, being principally an indicator of temperature, can show either a positive correlation with C (Fairbanks and Dodge, 1979), a negative relationship (Emiliani et al., 1978) or no relationship at all (Goreau, 1977; Swart, 1983; Weber and Woodhead, 1970). This change in correlation may be a result of the varying relationships between insolation and temperature at the different sampling sites (Fairbanks and Dodge, 1979; Swart, 1983). Recent work, however, suggests that this might not be the case (Swart et al., 1996) and that both the C and O isotopic compositions are strongly influenced by seasonal variations in the $\delta^{13} \mathrm{C}$ of the local waters (Cole et al., 1993; Swart et al., 1996).

Faster growing portions of coral skeletons are isotopically depleted in the heavier $\mathrm{C}$ and $\mathrm{O}$ isotopes relative to slower growing regions (Land et al., 1975a; McConnaughey, 1986), differences which cannot be explained as a result of change in temperature. McConnaughey proposed that the highest $\mathrm{C}$ and $\mathrm{O}$ isotopic values in the skeleton were those closest to isotopic equilibrium with the surrounding fluids and that the principal control of fractionation in the faster growing regions resulted from kinetic, not equilibrium effects. In the faster growing species $(>5 \mathrm{~mm} / \mathrm{yr}), \mathrm{C}$ and $\mathrm{O}$ isotopic values were suggested to exhibit a more consistent degree of disequilibrium. McConnaughey suggested therefore that if this portion of the skeletons is utilized for $\mathrm{C}$ and $\mathrm{O}$ isotopic analysis, constant disequilibrium could be compared and the $\mathrm{O}$ isotopic composition of the skeleton could be used as a proxy indicator of temperature and isotopic composition of the water. However, these results have not been confirmed in other studies (Swart et al., 1996; Leder et al., 1996).

\section{MATERIALS AND METHODS}

\section{Samples}

The coral used in this study was cored in 1986 and the growth rate reported by Hudson et al. (1994). At the time of coring this coral was described as being Montastraea annularis. Since this time it has been reported that corals previously reported as being $M$. annularis are in fact composed of three sibling species; $M$. annularis, $M$. faveolata, and $M$. franksi (Weil and Knowlton, 1994). According to this classification, the species examined by Hudson et al. (1994) and used in this study is M. faveolata.

\section{Coring and Density}

The coral was cored using conventional methods (Hudson, 1976) and subjected to standard X-radiography tech- niques in order to reveal density bands. Aluminum calibration wedges were included in the X-radiograph to analyze the density of the coral skeletons (Dodge and Kohler, 1985).

\section{Stable Carbon and Oxygen Isotopes}

Samples for stable $\mathrm{C}$ and $\mathrm{O}$ isotopes were obtained using a dental drill $(0.5 \mathrm{~mm})$ along exothecal skeletal elements. The resolution of sampling varied between 5 and 20 samples per year. A total of 2200 samples were drilled. The drilling method used was one in which discrete samples were drilled in a staggered manner in order to increase the sampling resolution. The carbonate samples were processed by an automated carbonate device attached to a Finnigan-MAT 251 gas ratio mass spectrometer. No pretreatment was used on the samples and the reaction was carried out at $90^{\circ} \mathrm{C}$. The external precision was calculated from replicate analyses of the internal laboratory calcite standard was $0.02 \%$ for $\delta^{13} \mathrm{C}$ and $0.03 \%$ for $\delta^{18} \mathrm{O}$. Data were corrected for the usual isobaric interferences.

After the analyses were completed, an age was assigned to each sample using the density banding, assuming that the sample taken from the density band formed during July of each year. For comparison with climate data and for statistical purposes, the data were interpolated to a common time interval of 1 sample per month using a linear interpolation method in cases where less than 12 samples were taken during one year and a rectangular method when greater than 12 samples were taken (Davies, 1973). In addition for each year samples were pooled into four seasonal averages representing periods of high and low rainfall. Growth rates were measured using the conventional approach of measuring the distance from the termination of high density bands.

\section{Statistical Analyses}

Statistical analyses were performed using Statistica. Interpolation and windowed regression was performed using a program written by the senior author. The single spectral analysis was performed using a program written by Ed Cook at LDGO.

\section{RESULTS}

\section{Oxygen}

The $\delta^{18} \mathrm{O}$ of the skeleton has a mean value of $-3.57 \%$ with an annual average variation of $0.79 \%$. Lower $\delta^{18} \mathrm{O}$ values usually occurred during the summer months. The timing of the dense band was assumed to occur during July (Hudson et al., 1977) and therefore during those years in which it is known that there was a stress band, for example, 1969 and 1970, the dense band formation appears like it formed during the portion of the year when the skeleton isotopically enriched in ${ }^{18} \mathrm{O}$ (winter) (Fig. 2a). Significant inter-annual variation in the mean oxygen isotopic composition also occurs (Fig. 3a), ranging from a 


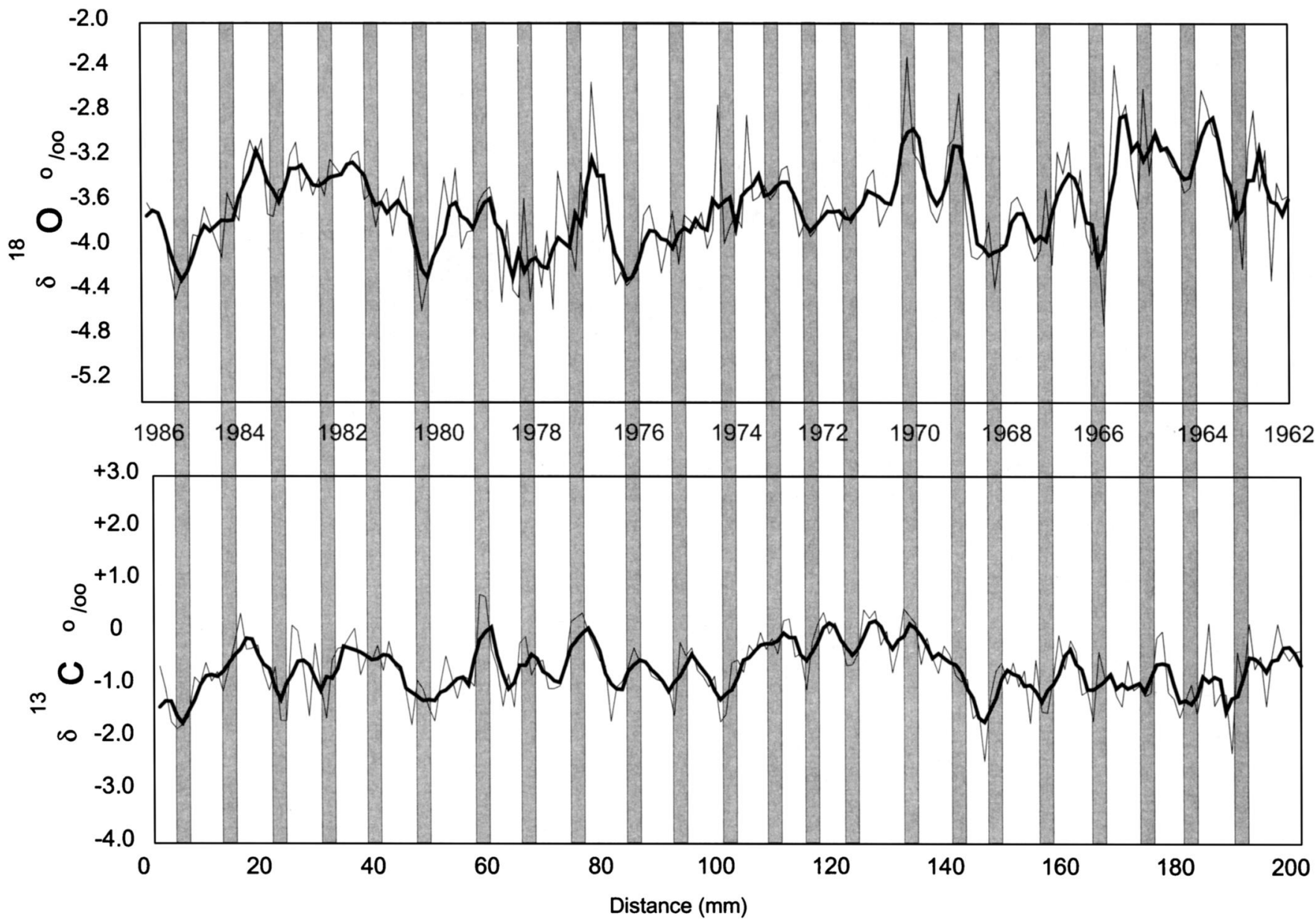

FIGURE 2-Time series data for a section of carbon and oxygen isotopic data between 1962 and 1986 . The heavy line indicates a four point moving average through the data. The position of the dense band is indicated by the location of the year and the dark shading. In most instances the dense band occurs during the portion of the year when the oxygen isotope composition is at its lowest values. In some years marked by severe cold winters, an additional density band is formed after the normal dense band. This causes the sense band to be wider during these years. An examination of the skeleton makes it appear that the dense band forms during the portion of the year when the $\delta^{18} \mathrm{O}$ is at its heaviest value. Two years during which it is known that there were extremely cold winters are 1969 and 1970 . In these years it appears that the dense band forms during the time of year then the $\delta^{18} \mathrm{O}$ values are at their highest values.

maximum $\delta^{18} \mathrm{O}$ of $-2.85 \%$ in 1840 to $-4.56 \%$ in 1935 . The annual range in $\delta^{18} \mathrm{O}$ only shows a slight positive correlation with the number a samples drilled within a year $(\mathbf{r}=$ +0.13 ; Fig. $4 \mathrm{a})$.

\section{Carbon}

The $\delta^{13} \mathrm{C}$ of the skeleton has a mean value of $-0.35 \%$ and an annual average range of $1.35 \%$ (Fig. 3), with the lowest values occurring during the late summer some months after the $\delta^{18} \mathrm{O}$ minimum. This phenomenon can be seen in a lag correlation plot of $\mathrm{C}$ and $\mathrm{O}$ (Fig. 5). The carbon isotopic composition appears to have declined from the mid 1930s to the present day. The annual range in $\delta^{13} \mathrm{C}$ only shows a slight positive correlation with the number a samples drilled within a year $(r=+0.13$; Fig. 4$)$.

\section{Growth Rate}

The density banding of this coral is very regular and distinct (Figs. 6, 7). The average growth rate is $7.87 \mathrm{~mm} / \mathrm{yr}$ (Hudson et al., 1994), and varies between 4.1 and 12.7 $\mathrm{mm} / \mathrm{yr}$ (Fig. 6). The rate gradually declined from over 10 $\mathrm{mm} / \mathrm{yr}$ during the 18 th century to approximately $7 \mathrm{~mm} / \mathrm{yr}$ between 1875 to the present day. Other corals of the same species on this reef have shown a decline in growth rate since the mid 1940s (Hudson et al., 1994). Although, there was no corresponding change in the skeletal $\delta^{18} \mathrm{O}$ over the time period, the $\delta^{13} \mathrm{C}$ decreases from 1940 to 1986.

\section{Density and Calcification}

The density of the coral skeleton varied between 0.82 and $1.54 \mathrm{gm} / \mathrm{cm}^{3}$ (Fig. 6). The rate of calcification, calculat- 

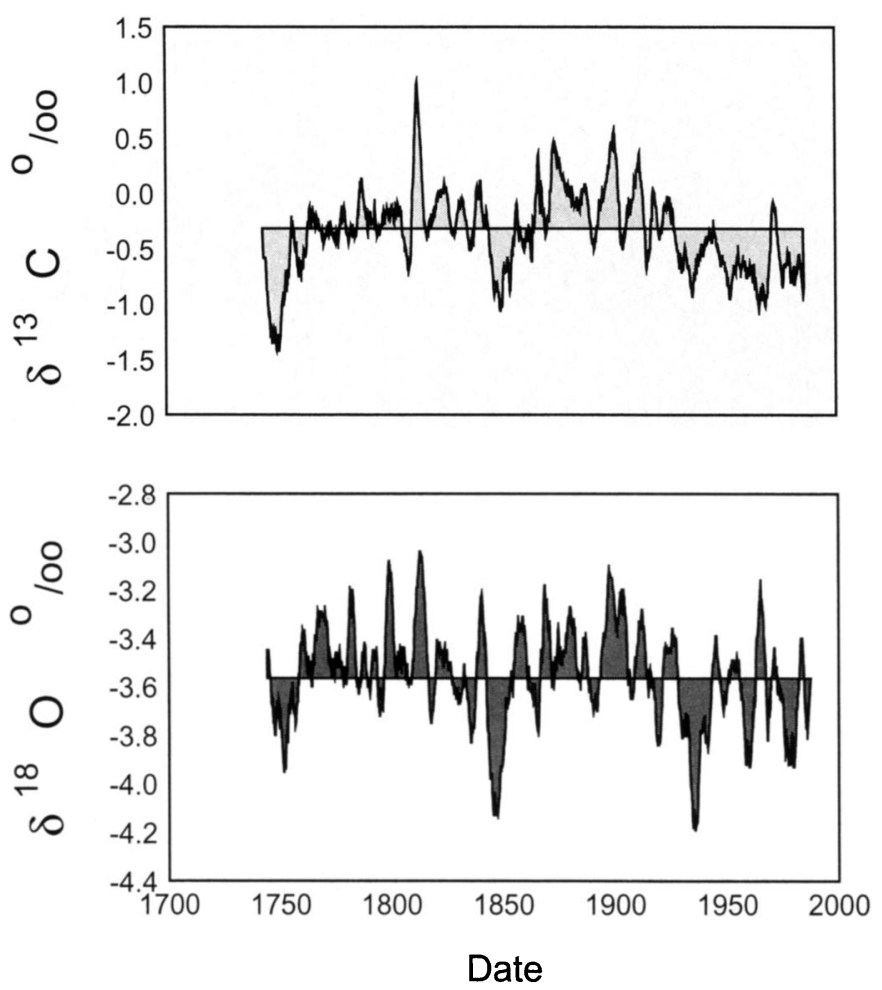

FIGURE 3-Time series for average oxygen isotopic composition for the entire record. Note the large interannual variations in the oxygen isotopic composition.

ed as a product of the linear extension times the density varied between 0.47 and $0.89 \mathrm{gm} / \mathrm{cm}^{3} / \mathrm{yr}^{-1}$.

\section{Spectral Analysis}

The frequency of $\delta^{18} \mathrm{O}$ and $\delta^{13} \mathrm{C}$ can be examined using spectral analysis methods in two manners, first by analyzing the entire data set and second by performing single spectral analysis, a technique which examines the change in a particular frequency with time.

\section{Oxygen}

Other than the annual cycle, the most important frequencies occur at 14.1 years (12.8\% of variance), $100-110$ years $(11.2 \%)$, 5-6 years $(8 \%), 19-20$ years $(8 \%), 47.6$ years $(6.5 \%), 17.9$ years $(5.1 \%)$, and 9.4 years $(5.1 \%)$ (Fig. $8 a)$. The deviation of some of these cycles with time is shown in Figure 9.

\section{Carbon}

The carbon isotopic composition shows a frequency of 111 years which accounts for $30.5 \%$ of the variance (Fig. $8 b$ ). This cycle appears to be similar in frequency and timing to the 100-110 cycle seen in the oxygen isotopic signal. Other important frequencies are 14.5 years $(5.4 \%), 26$ years $(6.4 \%), 11$ years $(7.1 \%)$, and 5-7 years $(4.8 \%)$ (Fig.
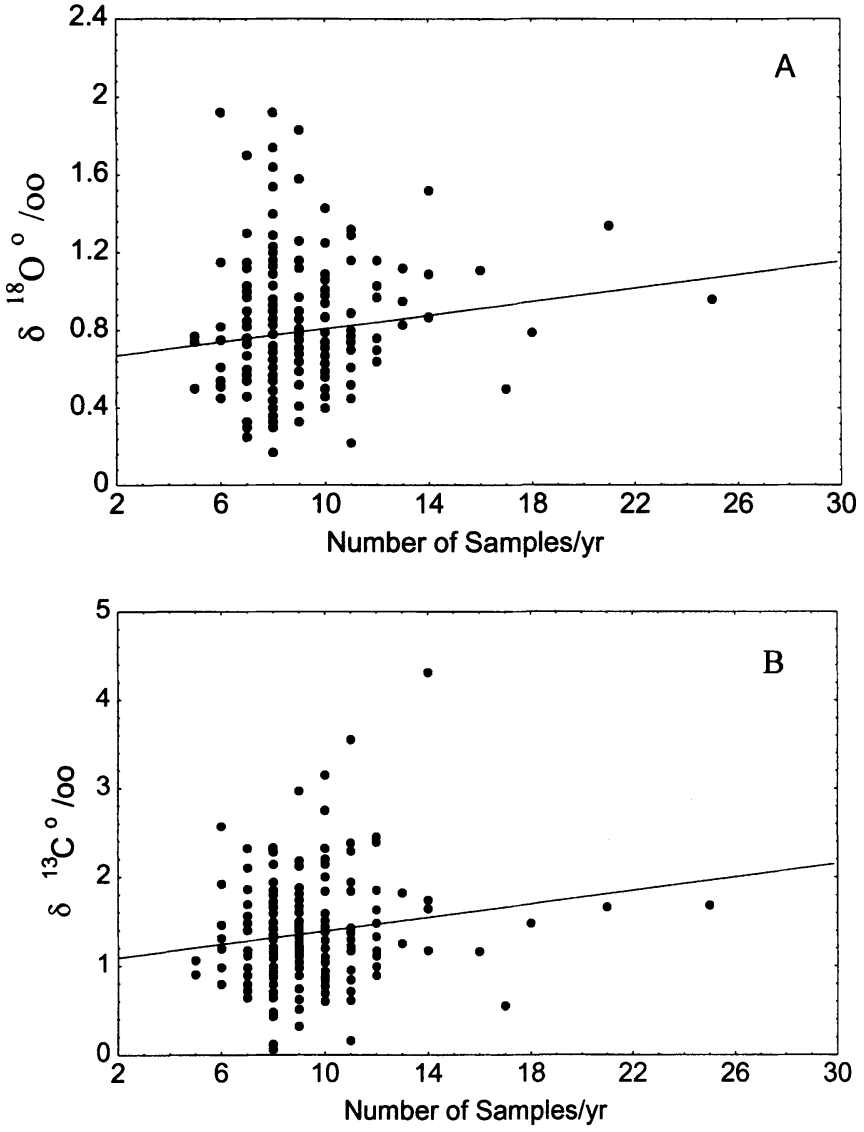

FIGURE 4-a) Correlation ( $r=0.13$ ) between number of samples taken within one year and the range of oxygen isotopes within a year. b)Correlation $(r=0.16)$ between the number of samples within a year and the range of carbon isotopes.

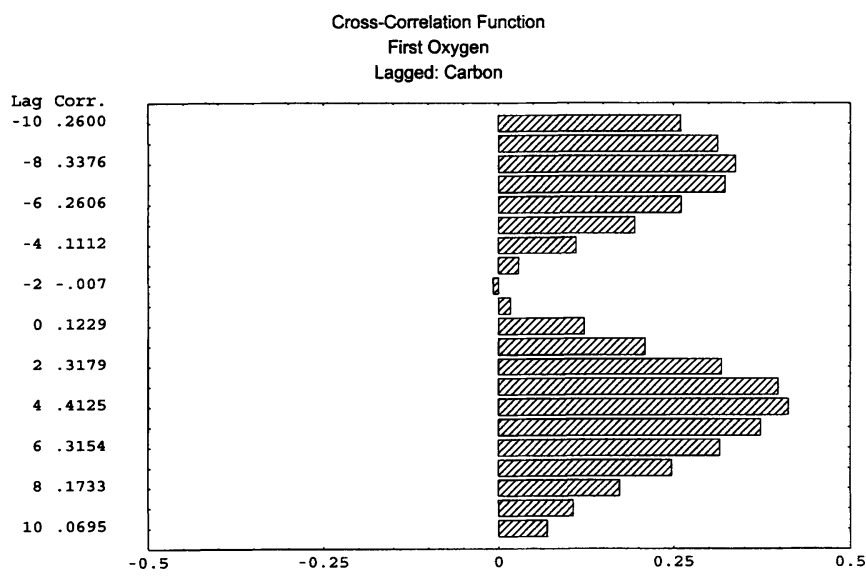

FIGURE 5-Lagged correlation between $\delta^{18} \mathrm{O}$ and $\delta^{13} \mathrm{C}$. This analysis shows that the maximum correlation between $C$ and $O$ is lagged by three months. This means that the minimum in the $\delta^{13} \mathrm{C}$ is preceded by a minimum in $\delta^{18} \mathrm{O}$ by three months. 

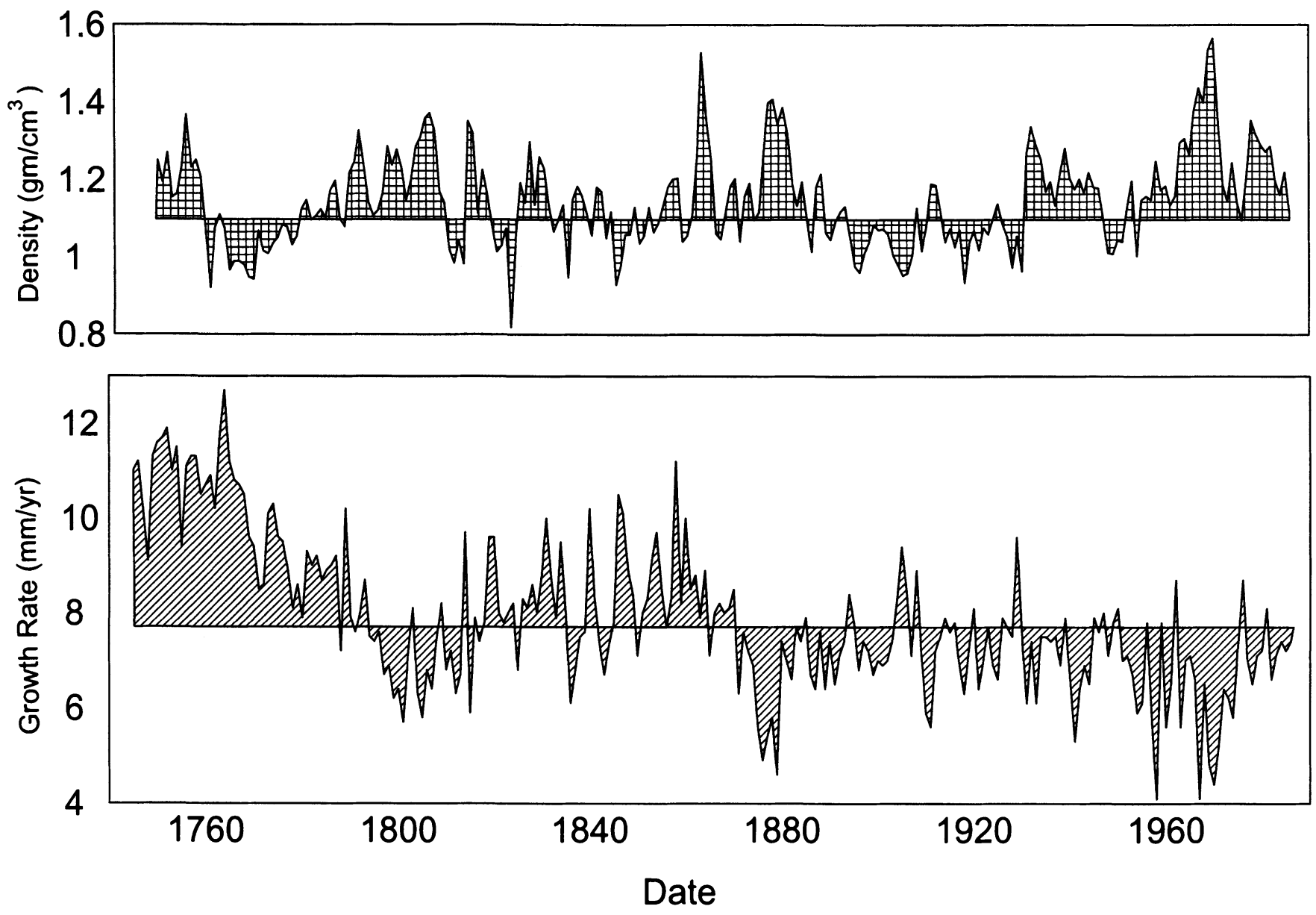

FIGURE 6-a) Density and b) growth rate for coral 4E. The major change in growth rate for this coral occurs at the start of the record. This change may reflect a change in growth orientation or partially shading or interaction with another coral.

10). A co-spectral density comparison between carbon and oxygen reveals several of these signals are common to both records including the $120,14,11$, and 5.5 year signals (Fig. $8 c)$.

\section{Growth Rate}

The two most important frequencies occur at 2-3 years (19\%) and 85 years (15\%). The 85 year frequency does not appear to be similar in timing to that seen in the carbon isotopic record (Figs. 11, 12).

\section{DISCUSSION}

\section{Oxygen}

Although no long term records of temperature exist for this particular site, it is possible to make use of two temperature records collected nearby. The first of these is a 12-year continuous record taken from the Cement Dome Site (Hudson et al., 1991) (Fig. 13). Although some differences can be expected between this site and where the cor- al used in this study was collected, these differences are only minor in extent (Leder et al., 1996). The second record is derived from COADS data and records a more general change in temperature between 1976 and 1986 as measured by ships in the $1^{\circ} \times 1^{\circ}$ square immediately adjacent to the Florida Keys. This record does not exhibit the range in temperature experienced by the Cement Dome Site, but nevertheless has a highly statistically significant correlation with the COADS data (Fig. 14). Using the Cement Dome data and a correlation with the COADS data set, it is possible to reconstruct a temperature record for the Cement Dome which extends in time back to 1900 . The skeletal $\delta^{18} \mathrm{O}$ record can then be correlated with temperature (Fig. 13). This correlation is statistically significant, although the slope of the relationship is less than that previously reported for this species (Fairbanks and Dodge, 1979). The difference in the slope between temperature and $\delta^{18} \mathrm{O}$ in this particular case is directly related to two features of the sampling technique used in this study.

(1) An insufficient number of samples were taken within each year. We sampled the coral at a resolution of between 6 and 25 samples in one year and determined only a 
1986
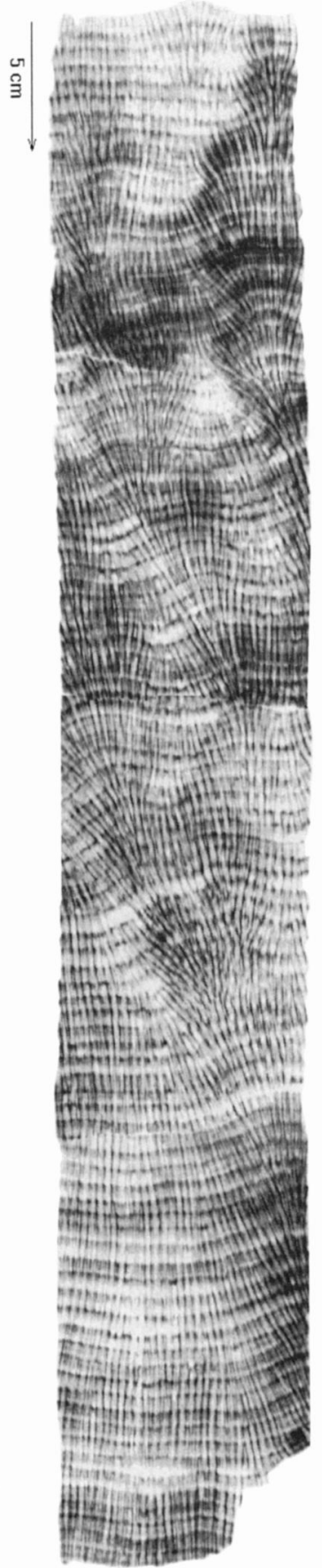
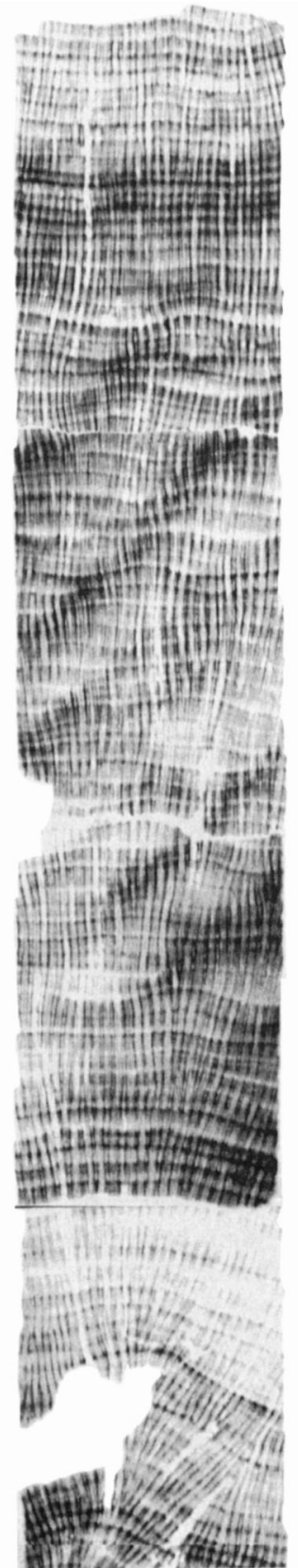
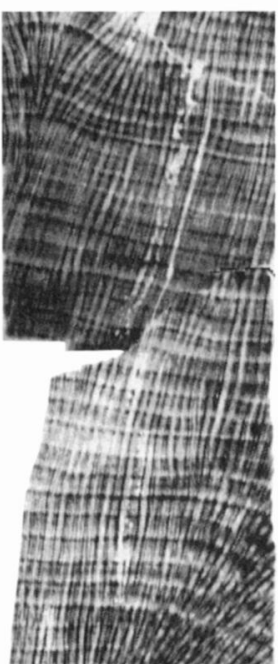

In.

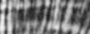

Iit) 32

sith

(5)

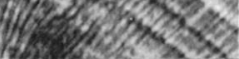

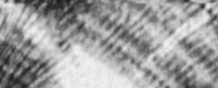
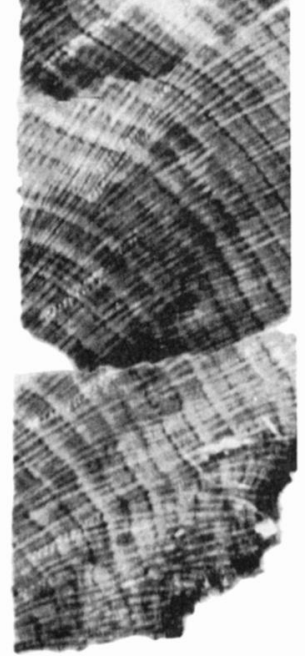

FIGURE 7-Composite X-radiograph from coral 4E. The coral was drilled in 1986.

slight increase in the annual range of both carbon and oxygen isotopes with increasing sample number (Fig. 4). Although this finding would tend to suggest an independence of the sampling rate with isotopic range, other more recent work (Leder et al., 1996) indicates that this is not the case. This later study suggests that an average sampling rate of $9 \mathrm{~s} / \mathrm{yr}$ should equate to an isotopic range of ap- proximately $1 \%$ or equivalent to $4.5^{\circ} \mathrm{C}$. The study of Leder et al. (1996) suggested that up to 50 samples per year were necessary to faithfully reconstruct temperature patterns in these corals.

(2) The sampling method which we employed in this study did not continually sample the skeleton and used large samples which not only sampled the theca regions, 

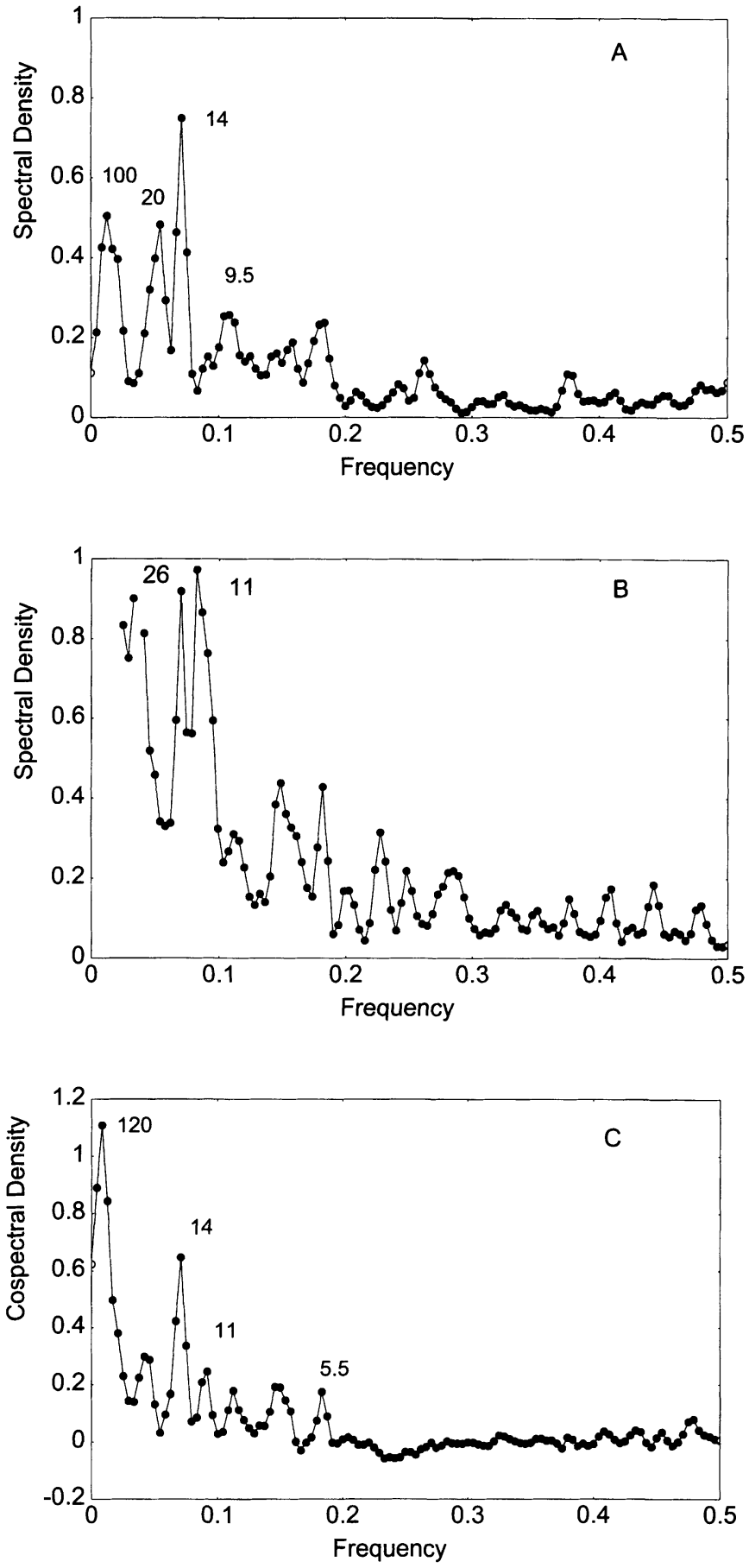

FIGURE 8-a) Spectral analysis of oxygen isotopic data showing peaks at $100,20,14$, and 9.5 years; b) Spectral analysis of carbon isotopic data showing peaks at 100-110, 26, 14.5, 11, and 5-7 years; c) Cross-spectral analysis between $\mathrm{C}$ and $\mathrm{O}$ isotopic data showing correlations at $120,14,11$, and 5.5 years.
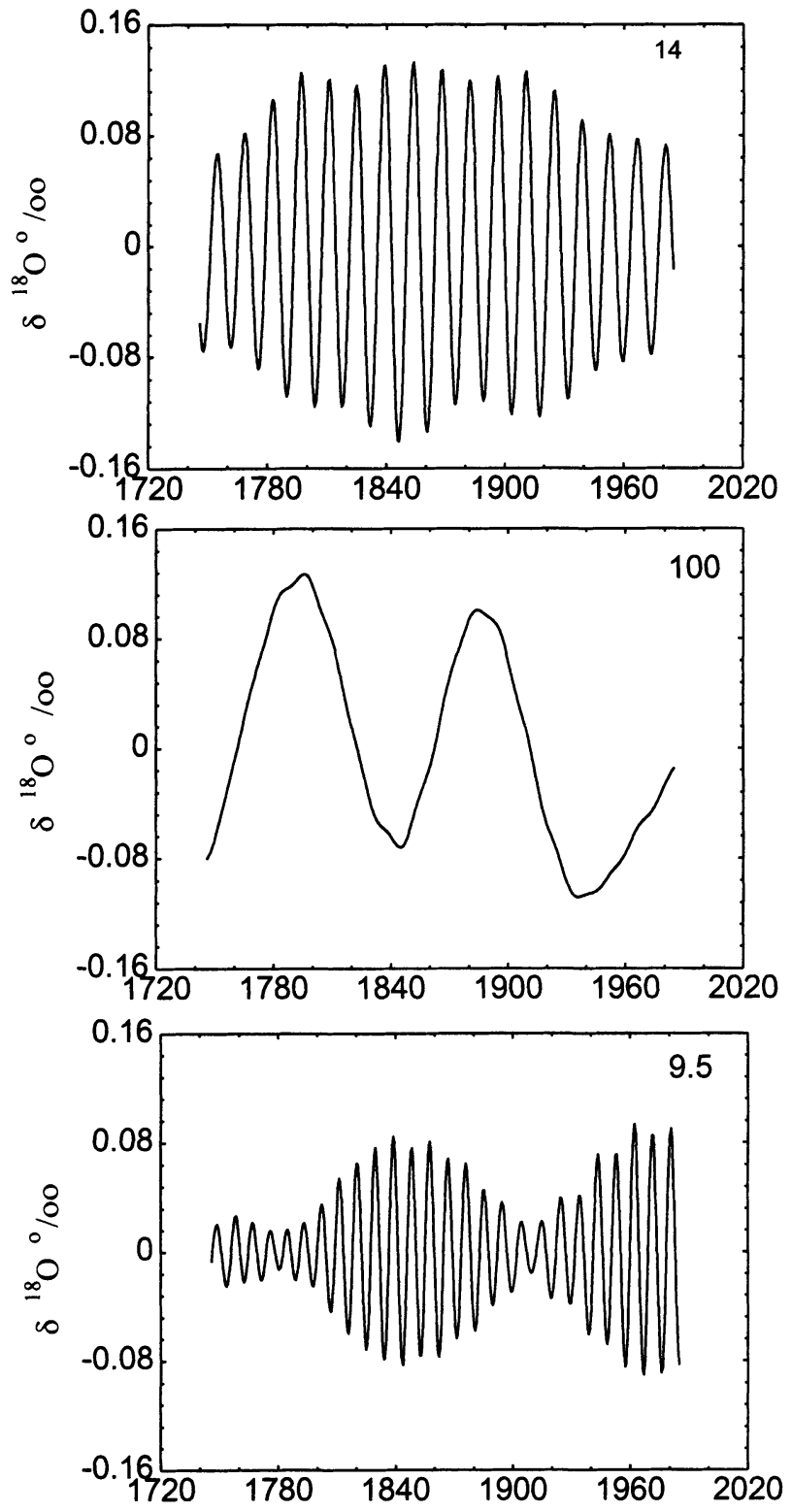

FIGURE 9-Single spectral analysis of $\delta^{18} \mathrm{O}$ data showing dominant frequencies $(14,100,9.5$, and 20$)$ explaining the inter-annual variation in the $\delta^{18} \mathrm{O}$ data.

but also some of the endotheca. The sampling method therefore missed a portion of the record during the year as well as averaged portions of the skeleton formed at slightly different times.

As a result of these factors the isotopic data collected in this study are not appropriate for the reconstruction of intra-annual temperatures. However, the data can be used to examine seasonal and annual isotopic patterns.

While intra-annual variations in the $\delta^{18} \mathrm{O}$ of the skeleton are correlatable with temperature, annual differences in temperature are not reflected in the annual $\delta^{18} \mathrm{O}$ values. Annual average $\delta^{18} \mathrm{O}$ values range from -4.35 to $-2.85 \%$. 

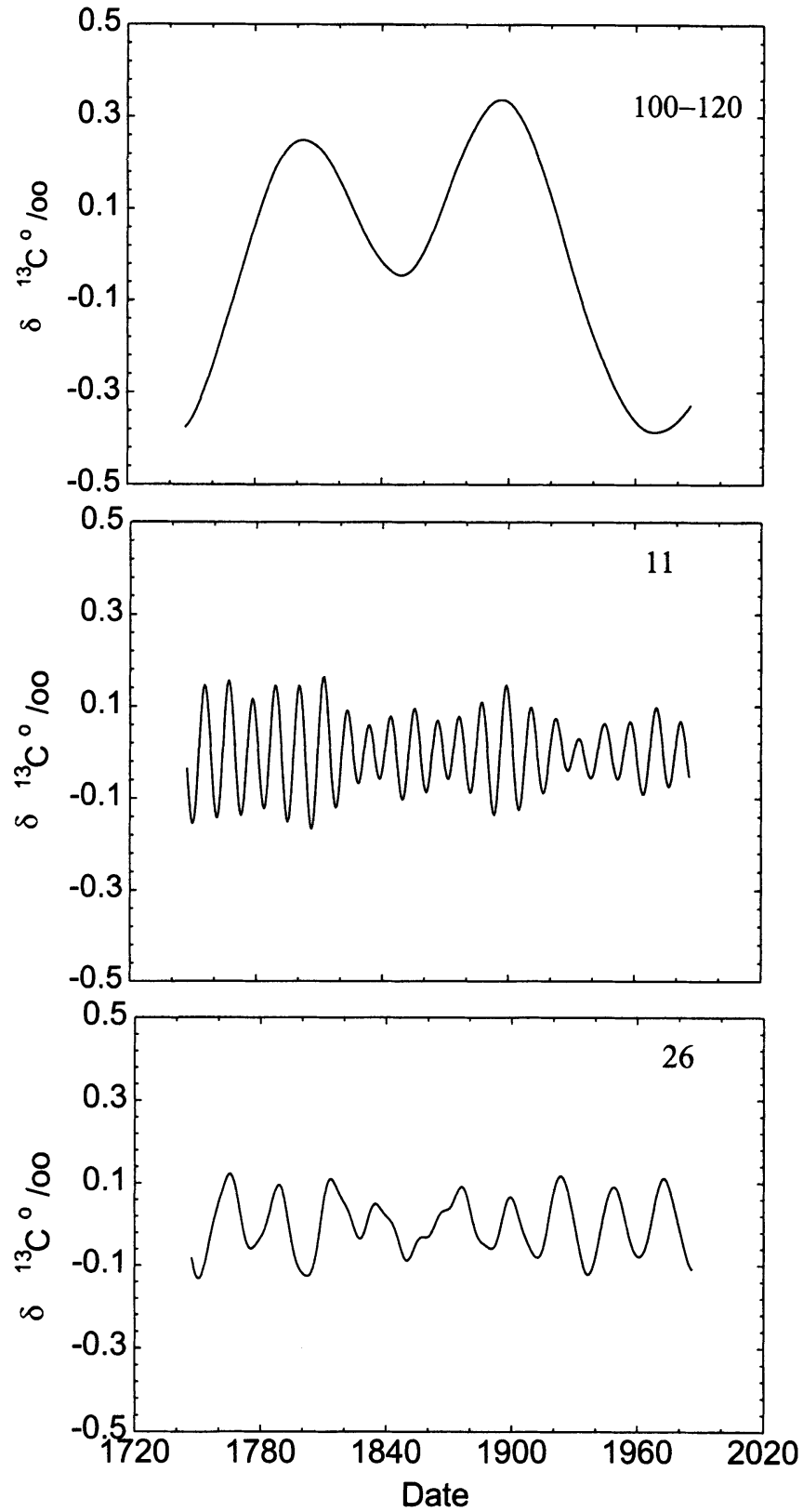

FIGURE 10 -Single spectral analysis of $\delta^{13} \mathrm{C}$ data showing dominant frequencies $(100-120,11,26$, and 14.5) explaining the inter-annual variation in the $\delta^{13} \mathrm{C}$ data.

This is equivalent to a $7^{\circ} \mathrm{C}$ change in temperature, significantly more than the $0.2^{\circ} \mathrm{C}$ change measured in the record from the Cement Dome Site. For example, Figure 15 shows the annual change in $\delta^{18} \mathrm{O}$ plotted on the same scale as would be expected if the entire inter-annual variation were a result of temperature change. As may be observed, there is simply insufficient variation in temperature to account for the $\delta^{18} \mathrm{O}$ variations in the coral skeleton. We believe that the reasons for the difference between the annual temperature and annual $\delta^{18} \mathrm{O}$ of the coral skeleton

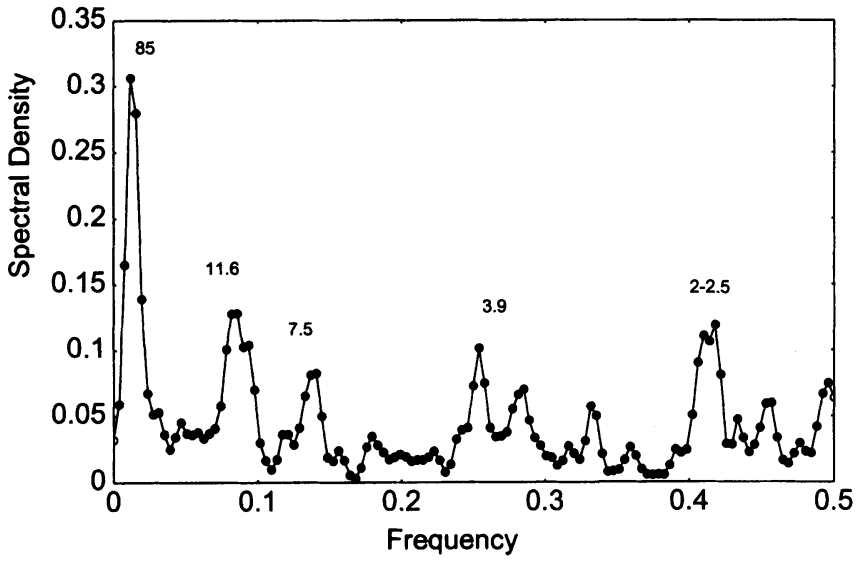

FIGURE 11-Spectral analysis of growth rate data. The most significant peaks correspond to a periodicity of $80-90$ years. There is a significant 2 year frequency which is probably caused by variation in the duration of the coral year (distance between density bands).

are related to long term changes in the oxygen isotopic composition of the waters. Changes in salinity alter the skeletal $\delta^{18} \mathrm{O}$ of the corals in two ways:

(1) An increase in the $\delta^{18} \mathrm{O}$ of the water occurs during periods of high evaporation of reefal waters, which might take place during periods of high temperature. Therefore, while the higher temperatures induce the corals to form skeleton with lower $\delta^{18} \mathrm{O}$ values, higher evaporation brought about by the same increase in temperature will increase the $\delta^{18} \mathrm{O}$ of the water.

(2) Salinity of the water is influenced through the addition of freshwater via precipitation or runoff from the adjacent land mass. Precipitation in South Florida is isotopically lower in $\delta^{18} \mathrm{O}$ and therefore high amounts of precipitation tend to lower the salinity and $\delta^{18} \mathrm{O}$ of the coastal waters. However, ground waters in Florida tend to be isotopically enriched in $\delta^{18} \mathrm{O}$ as a result of intense evaporation (Meyers et al., 1994). If the reefs were influenced by

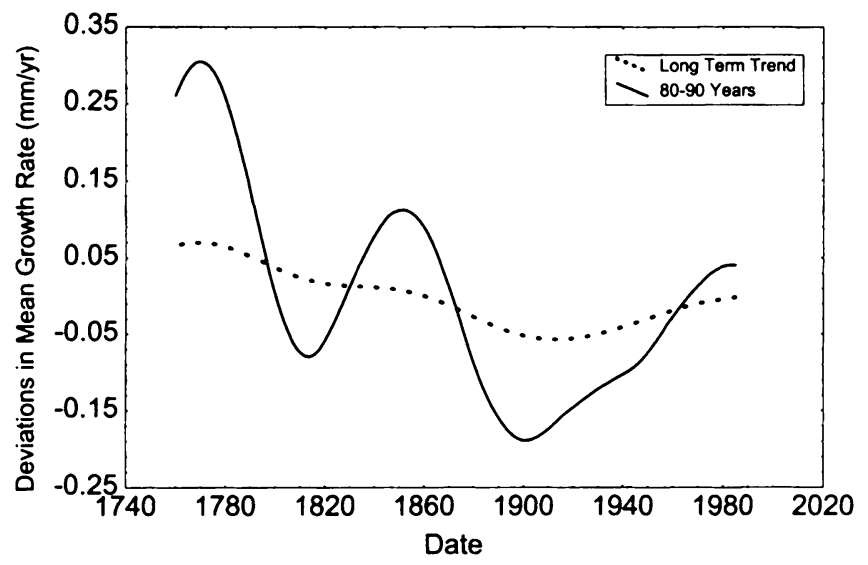

FIGURE 12-Single spectral analysis (SSA) of growth rate data. The long term trend corresponding to a reduction in growth rate is superimposed on the 80-90 year cycle. 


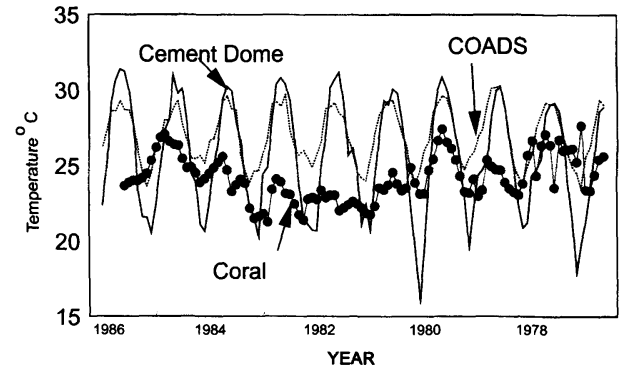

FIGURE 13-Temperature record between 1976 and 1986 from the Cement Dome Site combined with the COADS data for the $1^{\circ} \times 1^{\circ}$ square immediately adjacent to the Florida reef tract. See Figure 1 for location. Superimposed on this record is the temperature calculated from the $\delta^{18} \mathrm{O}$ of the coral skeleton. Single spectral analysis of $\delta^{18} \mathrm{O}$ data showing dominant frequencies $(100-120,11,26$, and 14.5) explaining the inter-annual variation in the $\delta^{18} \mathrm{O}$ data. Note the genera correlation between the coral and the Cement Dome record, but the significant reduction in the intr-annual range.

groundwater it might be expected that there would be a change in the relationship between salinity and $\delta^{18} \mathrm{O}$.

As precipitation and runoff are the greatest during the summer months in South Florida, we attempted to test this hypothesis by averaging the $\delta^{18} \mathrm{O}$ of the coral into three month periods coinciding with the drier and wetter portions of the year and correlating these data with precipitation and temperature data averaged in the same manner. The correlation coefficients between the $\delta^{18} \mathrm{O}$, temperature, and precipitation were determined using a stepwise approach in order to examine the change in the regression coefficient with time. In this method a correlation coefficient is determined for a subset of the data set ( $\mathrm{n}$ $=10$ ). The starting point of the correlation is then incremented by one and the process repeated. In this manner a time series of regression coefficients are calculated. The results of this analysis (Fig. 16) show that the correlation coefficient between both temperature and $\delta^{18} \mathrm{O}$ and precipitation and $\delta^{18} \mathrm{O}$ and time. The relationship between precipitation and $\delta^{18} \mathrm{O}$ for example changes between +0.6 and -0.7 . These correlations are significant at the $95 \%$ confidence limits. On further examination it appears that the

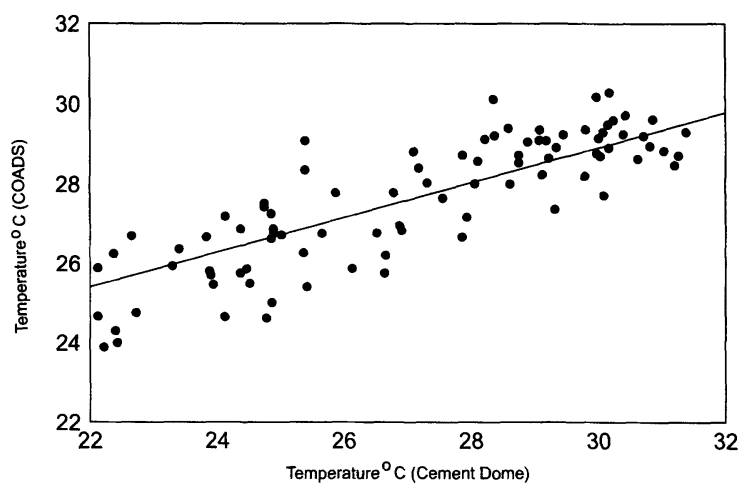

FIGURE 14-Correlation between COAD and Cement Dome temperature data.

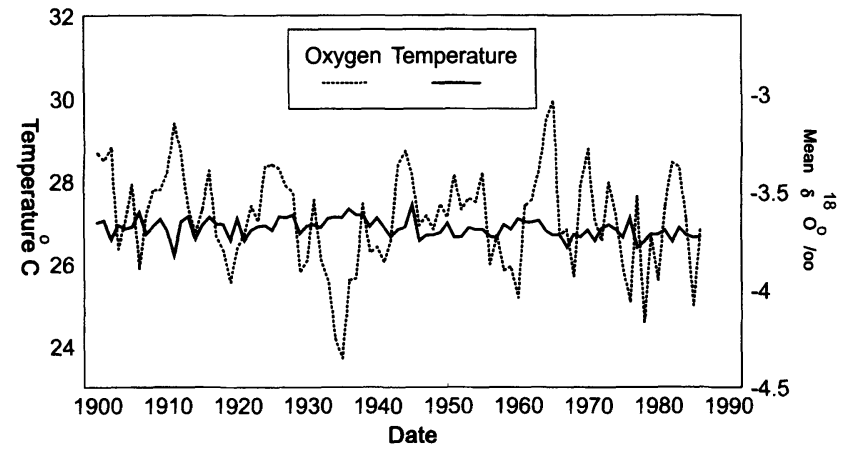

FIGURE 15-The annual temperature calculated for Cement Dome compared to the annual $\delta^{18} \mathrm{O}$ measured in the coral. The scale of the oxygen isotopes has been adjusted to correspond the observed temperature range. Note the much larger ranges in skeletal $\delta^{18} \mathrm{O}$ than can be accounted for by changes in annual average temperature.

periods which are characterized by negative correlations coefficients correspond to times of higher than average rainfall in the summer months. Conversely, positive correlation coefficients occur during periods of lower than average rainfall. A correlation coefficient between the calculated regression coefficients and precipitation is +0.61 ( $\mathrm{P}$ $>0.01$ ). The rationale for this trend can be explained by the varying nature of the $\delta^{18} \mathrm{O}$ of meteoric water in South Florida. During high rainfall (the summer rainfall for the months between July and September exceeds $52 \mathrm{~cm}$ ) water lower in $\delta^{18} \mathrm{O}$ reduces the salinity and the $\delta^{18} \mathrm{O}$ of the

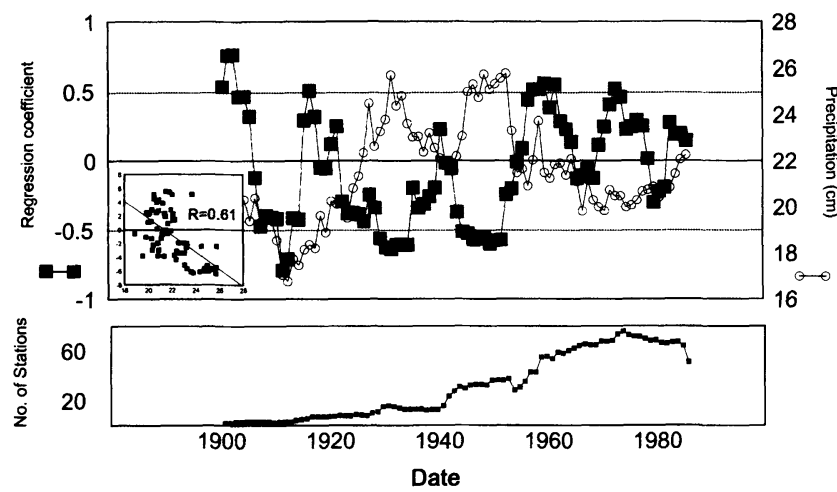

FIGURE 16-a) A windowed regression coefficient calculated between the summer precipitation (July, August, and September) and the $\delta^{18} \mathrm{O}$ from the coral calculated for the same period. Each window consist of ten years of data. The window is then incremented by one year and the analysis performed again. The regression coefficient varies from a positive correlation during years of below normal summer precipitation to negative values during wet years. The correlation coefficient between the windowed correlation coefficient and precipitation is -0.61 . The lines of +0.5 and -0.5 represent a statistically significant correlation at the $95 \%$ confidence level. The number of stations reporting data to the rainfall database used in the calculation are shown in (B). Note that during the early portion of the 20th century, there were only a few stations reporting precipitation data. Hence we believe that rainfall estimates were probably less reliable during this period and therefore the correlation between precipitation and skeletal $\delta^{18} \mathrm{O}$ was not as good. 


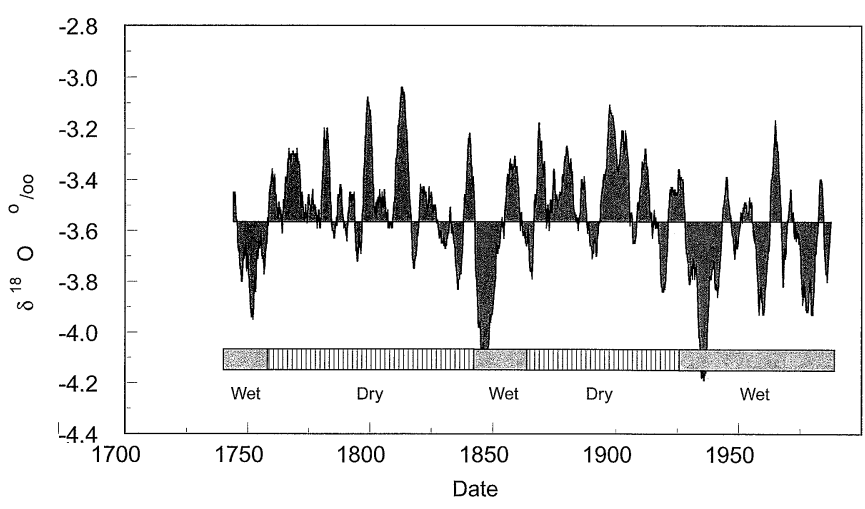

FIGURE 17-Interpretation of the $\delta^{18} \mathrm{O}$ record showing periods of wet weather during the 20th century preceded by drier weather in the 19th century. Wetter weather is indicated by $\delta^{18} \mathrm{O}$ values falling below the mean line. This cycle appears to correlate with a 100 year periodicity in the oxygen isotopic data. (Fig. 9).

coastal waters and results in an inverse correlation between the amount of precipitation and $\delta^{18} \mathrm{O}$. During times when precipitation is reduced, the correlation between $\delta^{18} \mathrm{O}$ and precipitation becomes reversed meaning that increases in rainfall correlate with higher water $\delta^{18} \mathrm{O}$ values. This type of correlation probably arises because freshwater enriched in ${ }^{18} \mathrm{O}$ from the Everglades affects Biscayne Bay and consequently the Florida reef tract. It is known that water in the surficial aquifer system of southern Florida is isotopically higher in $\delta^{18} \mathrm{O}\left(\delta^{18} \mathrm{O}=+1\right.$ to $\left.+2 \%\right)$. The correlation between the regression coefficient and the amount of summer precipitation therefore suggests two modes of influence on the reefs. Up to a certain amount of rainfall, the effect of increasing amounts of precipitation is to increase the amount of ${ }^{18} \mathrm{O}$ enriched water input from the surficial aquifer system onto the reefs. However, once rainfall increases past a certain treshhold, the amount of evaporation is reduced and the $\delta^{18} \mathrm{O}$ of the waters of Biscayne National Park are isotopically lowered as a result of direct input of rainwater which has not been affected by evaporation. This results in an inverse correlation between the amount of precipitation and $\delta^{18} \mathrm{O}$ at high amounts of precipitation. In spite of the seemingly good agreement shown in figure 16, there are two periods in which the relationship does not hold. The first period is prior to 1920 , a time during which the rainfall record in South Florida is based on only a relative few stations (Fig. 16). We can only speculate that the quality and quantity of the data were not as good as during later times. The second period is the last 20 years of the coral record. In the latter period it is possible that the relationship between salinity and $\delta^{18} \mathrm{O}$ were complicated by the construction of the canal system draining into Biscayne Bay (See earlier discussion) and the increased water demand by the urban areas.

If the correlation between summer precipitation and summer $\delta^{18} \mathrm{O}$ is valid then changes in the long term changes in the rainfall patterns in South Florida back to 1745 can be determined in a qualitative sense. Analysis of

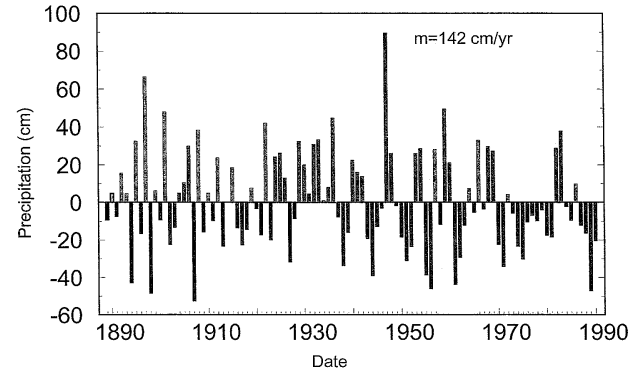

FIGURE 18-Precipitation data for the South Florida area derived from a compilation provided by the SFWMD (unpublished). Data are shown as negative or positive deviations from the mean value of 142 $\mathrm{cm} / \mathrm{yr}$. The wet period in the 20th century appears to have ended around 1970 and despite higher than normal precipitation in 1995, we may have entered a generally drier period as predicted from the coral isotopic data.

these patterns tend to suggest that the 20th century was considerably wetter than the 19 th and 18 th centuries with the exception of a prolonged wet spell between 1845 and 1855 and a period at the start of the record from 1745 to approximately 1755 (Fig. 17). This times of wet weather in South Florida appear to be taking place on an approximate 100 year cycle as shown in the SSA (Fig. 10). If this interpretation is correct we have just emerged from a period during which the precipitation in South Florida was greater than normal and are entering a time in which we can expect generally drier weather. In fact recent precipitation data from South Florida appear to indicate that we are presently in a relatively dry period (Fig. 18).

\section{Carbon}

Origins in the variations in the skeletal $\delta^{13} \mathrm{C}$ are related to both changes in the ambient $\delta^{13} \mathrm{C}$ of the dissolved inorganic carbon (DIC) of water masses affecting this particular portion of the Florida reef tract as well as changes in the physiology of the coral.

\section{Physiology}

At the present time, the most prevalent opinion is that the skeletal $\delta^{13} \mathrm{C}$ is controlled principally by an interrelationship between photosynthesis and respiration in the zooxanthellae and coral tissues (Swart, 1983). During periods of high photosynthesis, it is suggested that there is increased fixation of $\mathrm{CO}_{2}$ by the zooxanthellae leading to an isotopic enrichment in the carbon pool from which calcification takes place. Hence, coral skeletons formed during this period would be isotopically heavier or in other words contain greater amounts of ${ }^{13} \mathrm{C}$. Conversely, during times of lower photosynthetic activity or when the ratio of photosynthesis to respiration (P/R) falls, there will be less fractionation of the pool and increased additions of isotopically depleted carbon from respiration. It is suggested that the changing $P / R$ ratio in a coral throughout the year may therefore be responsible for producing a cyclic change in the carbon isotopic composition. During periods when 
the coral experiences a relatively high $\mathrm{P} / \mathrm{R}$ ratio (usually greater than unity), corals will produce isotopically heavy skeletons and during periods when there is low $\mathrm{P} / \mathrm{R}$, skeletons may be isotopically lighter in $\delta^{13} \mathrm{C}$. Changes in the $\mathrm{P} / \mathrm{R}$ ratio of corals are known to be influenced by photoperiod, photointensity, and temperature; longer photoperiods and higher temperatures promoting higher $\mathrm{P} / \mathrm{R}$ ratios. It has been proposed, therefore, that the relationship between the timing of maximum temperature and maximum insolation at a particular locality will govern the timing of the correlation between carbon and oxygen isotopes (Fairbanks and Dodge, 1979). If the maximum insolation occurs during the warmer times of the year then the $\delta^{13} \mathrm{C}$ will be inversely related to $\delta^{18} \mathrm{O}$. On the other hand if maximum photoperiod occurs during the colder portion of the year then the two isotopes will be positively related. In the case of the corals in this study, $\delta^{13} \mathrm{C}$ and $\delta^{18} \mathrm{O}$ are out of phase by approximately three months. Hence the minimum skeletal $\delta^{13} \mathrm{C}$ occurs on average three months after the warmest temperature, sometime between September and October. The most positive skeletal $\delta^{13} \mathrm{C}$ within a year appears to occurs between April and May of each year. How the intra-annual changes in $\delta^{13} \mathrm{C}$ relate to the accepted hypotheses regarding carbon fractionation in coral skeletons cannot be resolved in this study. However, the inter-annual correlation between $\delta^{18} \mathrm{O}$ and $\delta^{13} \mathrm{C}$ is consistent with the hypothesis regarding the input of freshwater as a result of increase precipitation. During years of increased precipitation, one can expect an increase in cloud cover and a consequent reduction in light. According to the prevalent hypothesis regarding the incorporation of stable carbon isotopes into coral skeletons, a reduction of light should result in less ${ }^{13} \mathrm{C}$ in the skeleton and in this case a positive correlation between $\delta^{18} \mathrm{O}$ and $\delta^{13} \mathrm{C}$. The positive correlation between $\delta^{18} \mathrm{O}$ and $\delta^{13} \mathrm{C}$ in the annual data is also consistent with input of freshwater containing low $\delta^{18} \mathrm{O}$ and low $\delta^{13} \mathrm{C}$ values. It should however be pointed out that a recent study (Swart et al., 1996) determined that there was an inverse correlation between skeletal $\delta^{13} \mathrm{C}$ and the ratio of photosynthesis to respiration in corals from this locality between 1988 and 1991. The relationship was unexpected and it is likely that it results from other changes in other parameters affecting the skeletal $\delta^{13} \mathrm{C}$ during this period which also happened to correlate with the $\mathrm{P} / \mathrm{R}$ ratio. For this reason it would be incorrect to use the carbon isotopic ratio to make any interpretations regarding changes in insolation.

\section{Reproduction}

It has been suggested that the energy expended during the formation of gametes may be causative in the formation of density bands and carbon isotopic depletion in coral skeletons (Kramer et al., 1993; Gagan et al., 1994). Studies carried out by Kramer et al. (1993) on several species from Joulters Cay in the Bahamas including Montastraea faveolata were inconclusive in this regard.

\section{Autotrophy vs. Heterotrophy}

A further influence upon the isotopic composition of the skeleton may arise according to whether the coral varies between autotrophy or heterotrophy during different portions of the year. During periods of heterotrophy coral tissues may assume a more depleted isotopic composition as they feed on zooplankton.

\section{Variations in the Carbon Isotopic Composition of the DIC}

Previous work has shown that changes in the $\delta^{13} \mathrm{C}$ of the DIC of between 1 and $2 \%$ can occur seasonally in reefal waters off Florida (Swart et al., 1996). The origin of the variations remain unknown, but it has been speculated that they arise either as a result of seasonal changes in productivity in the reefal waters or the reef could be influenced by seasonal changes in the amount of freshwater originating from the Everglades. This latter explanation would tend to support the notion that changes in the $\delta^{18} \mathrm{O}$ are a result of outflow from the mainland. However, we do not think that this is the primary intra-annual control of $\delta^{13} \mathrm{C}$ for two reasons. First, changes in the $\mathrm{C}$ and $\mathrm{O}$ isotopic compositions are lagged by several months. If the intraannual changes in carbon and oxygen were a result of the input of freshwater we would expect no lag in the correlation. Second, there is no correlation between skeletal $\delta^{13} \mathrm{C}$ and precipitation, suggesting the precipitation is not the primary control on the carbon isotopic composition.

\section{Long Term Changes in the Skeletal $\delta^{13} \mathrm{C}$}

The $\delta^{13} \mathrm{C}$ of the coral skeleton appears to have been in decline since the 1900's although the origin of this decrease is a matter of speculation. It is possible that the decrease in $\delta^{13} \mathrm{C}$ relates in a change in land usage in adjacent coastal communities coupled with increased runoff or sewage from Miami (Hudson et al., 1994). These changes might cause an increased input of ${ }^{12} \mathrm{C}$ into the coastal environment. A further possibility is that the decrease relates to the increase in the amount of anthropogenically derived $\mathrm{CO}_{2}$ with low $\delta^{13} \mathrm{C}$ values in the atmosphere. A decrease in the atmospheric $\delta^{13} \mathrm{C}$ of $0.6 \%$ o has been noted between 1955 and 1977 (Keeling, 1979). This approximately the same decrease as found in the coral skeleton over the same time period.

\section{CONCLUSIONS}

1) The $\delta^{18} \mathrm{O}$ of the coral skeleton represented by the summer months shows a bimodal correlation with the amount of precipitation during July, August, and September. During years during which the precipitation is greater than the average, precipitation is inversely correlated with $\delta^{18} \mathrm{O}$ reflecting the input of isotopically depleted precipitation. In contrast, when precipitation is below normal there is a positive relationship between precipitation and $\delta^{18} \mathrm{O}$. This relationship reflects the input of isotopically heavy water from the Everglades. 
2) The $\delta^{18} \mathrm{O}$ record of the coral which extends back to 1745 suggests that the majority of the 19th and 18th centuries were comparatively dry compare to the early portion of the 20th century.

3) The decrease in the $\delta^{13} \mathrm{C}$ of the skeleton between 1940 and the present day may either be related to a change in the $\delta^{13} \mathrm{C}$ of the local DIC or related to a long term decrease in the $\delta^{13} \mathrm{C}$ of the atmosphere related to increases in fossil fuel derived $\mathrm{CO}_{2}$.

\section{ACKNOWLEDGMENTS}

The authors would like to thank R. Halley and J. Leder for helpful discussions and logistical support. Numerous students helped with the sample preparation, but in particular we thank Janet Macdaneld and Michelle Lopez. We thank E. Cook for making the single spectral analysis program available and R. Dunbar for providing the version of Windows. This project was funded by NSF grant OCE-8900005 to P.K. Swart and A. Szmant, and OCE8907101 to R.E. Dodge.

\section{REFERENCES}

COLE, J.E., FAIRBANKS, R.G., and SHEN, G.T., 1993, Recent variability in the Southern Oscillation: isotopic results from a Tarawa coral: Science, v. 260, p. 1790-1793.

DoDGE, R.E., and VAISNYS, J.R., 1975, Hermatypic coral growth banding as environmental recorder: Nature, v. 258, p. 706-708.

DODGE, R.E., and LANG, J.C., 1983, Environmental correlates of hermatypic coral (Montastrea annularis) growth on the East Flower Gardens Bank, northwest Gulf of Mexico: Limnology and Oceanography, v. 28, p. 228-240.

DoDGE, R.E., and GILBERT, T.R., 1984, Chronology of lead pollution contained in banded coral skeletons: Marine Biology, v. 82, p. 913.

DODGE, R.E., and KOHLER, K., 1985, Image analysis of coral skeletons for extension rate, calcification rate, and density: Advances in Reef Science, Joint Meeting of Atlantic Reef Committee and the International Society of Reef Studies, p. 31-32.

DRUFFEL, E.M., 1982, Banded corals: Changes in oceanic carbon-14 during the Little Ice Age: Science, v. 218, p. 13-19.

DRUFFEL, E.M., 1987, Bomb radiocarbon in the Pacific: Annual and seasonal time scale variations: Journal of Marine Research, v. 45, p. 667-698.

Emiliani, C., Hudson, J.H., Shinn, E.A., and George, R.Y., 1978, Oxygen and carbon isotopic growth record in a reef coral from the Florida Keys and a deep-sea coral from Blake Plateau: Science, v. 202, p. 627-629.

FaIRBANKS, R.G., and DoDGe, R.E., 1979, Annual periodicity of the ${ }^{18} \mathrm{O} /{ }^{16} \mathrm{O}$ and ${ }^{13} \mathrm{C} /{ }^{12} \mathrm{C}$ ratios in the coral Montastraea annularis: Geochimica et Cosmochimica Acta v. 43, p. 1009-1020.

Gagan, M.K., ChIVAS, A.R., and IsDale, P.J., 1994, High-resolution isotopic records from corals using ocean temperature and massspawning chronometers: Earth and Planetary Science Letters, v. 121, p. 549-558.

$\rightarrow$ GOREAU, T.J., 1977, Coral skeletal chemistry: physiological and environmental regulation of stable isotope and trace metals in Montastrea annularis: Proceedings of the Royal Society (Series B) v. 196, p. 291-315.

HuDSON, J.H., 1981, Growth rates in Montastrea annularis: As record of environmental change in Key Largo corals reef marine sanctuary, Florida: Bulletin of Marine Science, v. 31, p. 444-459.

Hudson, J.H., ShinN, E.A., Halley, R.B., and LiDZ, B., 1976, Sclero- chronology-a tool for interpreting past environments: Geology, v. 4 , p. $360-364$.

Hudson, J.H., Halley, R.B., JosePH, A.J., LiDZ, B.H., and SHROEDER, D., 1991, Long-term thermograph records from the upper Florida Keys: United States Geological Survey Open-File report \#91-344.

HuDSON, J.H., HANSON, K., HALLEY, R.B., and KINDINGER, J.L., 1994, Environmental implications of growth rate change in Montastrea annularis: Biscayne National Park, Florida Bulletins of Marine Science, v. 54, p. 647-669.

ISDALE, P., 1984, Fluorescent bands in massive corals record centuries of coastal rainfall: Nature, v. 310, p. 578-579.

$\rightarrow$ KEELING, C.D., 1979, Recent trends in ${ }^{13} \mathrm{C} /{ }^{12} \mathrm{C}$ ratio of atmospheric carbon dioxide: Nature, v. 277, p. 121-122.

KeITH, M.L., and WeBER, J.N., 1964, Systematic relationships between carbon and oxygen isotopes in carbonates deposited by modern corals and algae: Science, v. 150, p. 498-501.

KRAMER, P.A., SwaRT, P.K. and SzmanT, A.M., 1993, The influence of different sexual reproductive patterns on density banding and stable isotopic compositions of corals: Proceedings of the 7th International Coral Reefs Symposium, Guam, v. 1, p. 222.

LAND, L.S., LANG, J.C., and BARNES, D.J., 1975a, Extension rate: A primary control on the isotopic composition of West Indian (Jamaican) scleractinian reef coral skeletons: Marine Biology, v. 33, p. 221-233.

LAND, L.S., LANG, J.C., and SMITH, B.N., 1975b, Preliminary observations on the carbon isotopic composition of some reef coral tissues and symbiotic zooxanthellae: Limnology and Oceanography, v. 20, p. 283-287.

LEDER, J.J., SzMANT, A., and SwarT, P.K., 1991, The effect of prolonged bleaching on skeletal banding and stable isotopic composition in Montastrea annularis: Coral Reefs, v. 10, p. 19-27.

LEDER J.J., SwART, P.K., SzMANT, A., and DoDGE, R.E., 1996, The origin of variations in the isotopic record of scleractinian corals: I Oxygen, Geochimica Cosmochimica Acta, v. 60, p. 2857-2870.

MANLEY, 1974, Central England temperatures: monthly means 1959 to 1973: Quarterly Journal of the Royal Meteorological Society, v. 100 , p. 389-405.

MeYers, J., Swart, P.K., and Meyers, J., 1993, Geochemical evidence for groundwater behavior in an unconfined aquifer, South Florida: Journal of Hydrology, v. 148, p. 249-272.

MCCONNAUGHEY, T.A., 1986, Oxygen and carbon isotope disequilibria in Galapagos corals: Isotopic thermometry and calcification physiology: Unpublished Ph.D. Dissertation, University of Washington, $340 \mathrm{p}$.

MCCoNNAUGHEY, T.A., $1989 \mathrm{a},{ }^{13} \mathrm{C}$ and ${ }^{18} \mathrm{O}$ disequilibrium in biological carbonates: I. Patterns: Geochimica Cosmochimica Acta, v. 53, p. 151-162.

MCConNAUGhey, T.A., $1989 \mathrm{~b},{ }^{13} \mathrm{C}$ and ${ }^{18} \mathrm{O}$ disequilibrium in biological carbonates: II. In vitro simulation of kinetic effects: Geochimica Cosmochimica Acta, v. 53, p. 151-162.

ORTner P.B., Lee T.N., Milne P.J., Zidka R.G., Clarke M.E., PoDESTA G.P., Swart P.K., Testa P.A., ATKInson., L.P., and JohNSON W.R., 1995, Mississippi River flood waters reached the Gulf Stream: Geophysical Research Letters, v. 100, p. 13,595-13,601.

PARKER, G., 1984, Hydrology of the Pre-drainage system of the Everglades in Southern Florida, in GLEASON, P.J., ed., Environment of South Florida Present and Past II: Miami Geological Society, p. $28-37$.

PATZOLD., J., 1984, Growth rhythms recorded in stable isotopes and density bands in the reef coral Porites lobata (Cebu) Philippines: Coral Reefs, v. 3, p. 87-90.

SCHNEIDER, R.C., and SMITH, S.V., 1983, Skeletal Sr content and density in Porites spp. in relation to environmental factors: Marine Biology, v. 66, p. 121-131.

SwART, P.K., 1983, Carbon and oxygen isotope fractionation in scleractinian corals: a review: Earth-Science Reviews, v. 19, p. 51-80.

SwART, P.K., and COLEMAN, M.L., 1980, Isotopic data for scleractini- 
an corals explain their palaeotemperature uncertainty: Nature, $v$. 283 , p. 557-559.

Swart, P.K., STERnBerg, L., Steinen, R., and HARRIson, S.A., 1989, Controls on the oxygen and hydrogen isotopic composition of waters from Florida Bay: Chemical Geology, v. 79, p. 113-123.

SwarT, P.K., LEDER, J.J., SzMANT A., and DodGE, R.E., 1996, The origin of variations in the Isotopic Record of Scleractinian Corals: II Carbon, Geochimica Cosmochimica Acta, v. 60, 2871-2886.

WEBER, J.N., and WoODHEAD, P.M.J., 1970, Carbon and oxygen isotope fractionation in the skeletal carbonate of reef-building corals: Chemical Geology, v. 6, p. 93-117.

WeBER, J.N., and WoOdHEAD, P.M.J., 1972, Temperature dependence of oxygen-18 concentration in reef coral carbonates: Journal of Geophysical Research, v. 77, p. 463-473.

WEBER, J.N., WhitE, E.W., and WEBER, P.H., 1975, Correlation of density banding in reef coral skeletons with environmental parameters: the basis for interpretation of chronological records preserved in the coralla of corals: Paleobiology, v. 1, p. 137-149.

Weber, J.N., DeINES P., WeBER P.H., and BAKER, P.A., 1976, Depthrelated changes in the C-13/C-12 ratio of skeletal carbonate deposited by the Caribbean reef-frame-building coral Montastrea annularis: Geochim. Cosmochim. Acta, v. 40, p. 31-39.

WEIL E., and KNOWLTON, N., 1994, A multi-character analysis of the Caribbean coral Montastraea annularis (Ellis and Solander, 1786) and its two sibling species, M. faveolata (Ellis and Solander, 1786) and M. Franksi (Gregory, 1895), Bulletin of Marine Science, v. 55, p. 151-175.

WeIL, S.M., BudDEMEIER, R.W., SMITH, S.V., and KROOPNICK, P.M., 1981, The stable isotopic composition of coral skeletons: control by environmental variables: Geochimica Cosmochimica Acta, v. 45, p. 1147-1153. 